\title{
EXPRESSION OF THE E1 GENE OF MOUSE HEPATITIS VIRUS (MHV A59) IN VIVO
}

AND IN VITRO

Heiner Niemann, Thomas Mayer, Manfred Wirth, and Teruko Tamura

Institut für Medizinische Virologie der Justus-Liebig-Universität

Frankfurter Str. 107, D-6300 Giessen, FRG.

\section{Introduction}

The structural model of MHV A59 as proposed by Sturman and Holmes (1) suggests three functional domains for the transmembrane glycoprotein E1 (Figure 1a): The extraviral domain carries exclusively 0-linked oligosaccharides which exhibit in conjunction with the aminoterminal amino acid sequence, Ser-Ser-Thr-Thr-, blood group M-activity (2). The intramembranal part consists of two hydrophobic stretches containing 19 and 56 amino acids. These span the viral membrane at least three times $(3,4)$. The intraviral part of $E 1$ interacts with the viral nucleocapsid and thus plays an important role in the early stages of virus formation (1).

Cell fractionation studies of MHV A59-infected cells indicated that the El protein was synthesized at membrane associated polysomes (5) but was absent from the plasma membrane. The intracellular distribution of E1 was restricted to perinuclear regions (6) and thus paralleled the sites at which budding of virus particles was observed $(7-9)$. Theoretically, this particular intracellular distribution could be explained in one of the two following manners (Figure 1b):

i) The El-protein could be trapped on its way to the plasma membrane by an efficient interaction with other coronavirus structural components. ii) Alternatively, the E1 peptide could carry an endogenous transport signal into smooth vesicles which subsequently constitute the sites for virus particle formation.

To distinguish between these possibilities, it was essential to express the El-gene in the absence of other coronavirus structural components. Based on the results obtained by expression of the E1-gene under control of the early promoter of an SV40 vector, as well as data resulting from microinjection of in vitro transcribed mRNA into various cell lines we show here that the E1-protein indeed contains a signal for perinuclear accumulation. Using site-directed mutagenesis and deletion analyses we have defined the internal signal for membrane integration. In addition, we demonstrate that a conversion of the 0 -glycosylation sites at the $\mathrm{N}$-terminus of $\mathrm{El}$ into an $\mathrm{N}$-glycosylation site does not influence the characteristic transport properties of the E1-protein. 


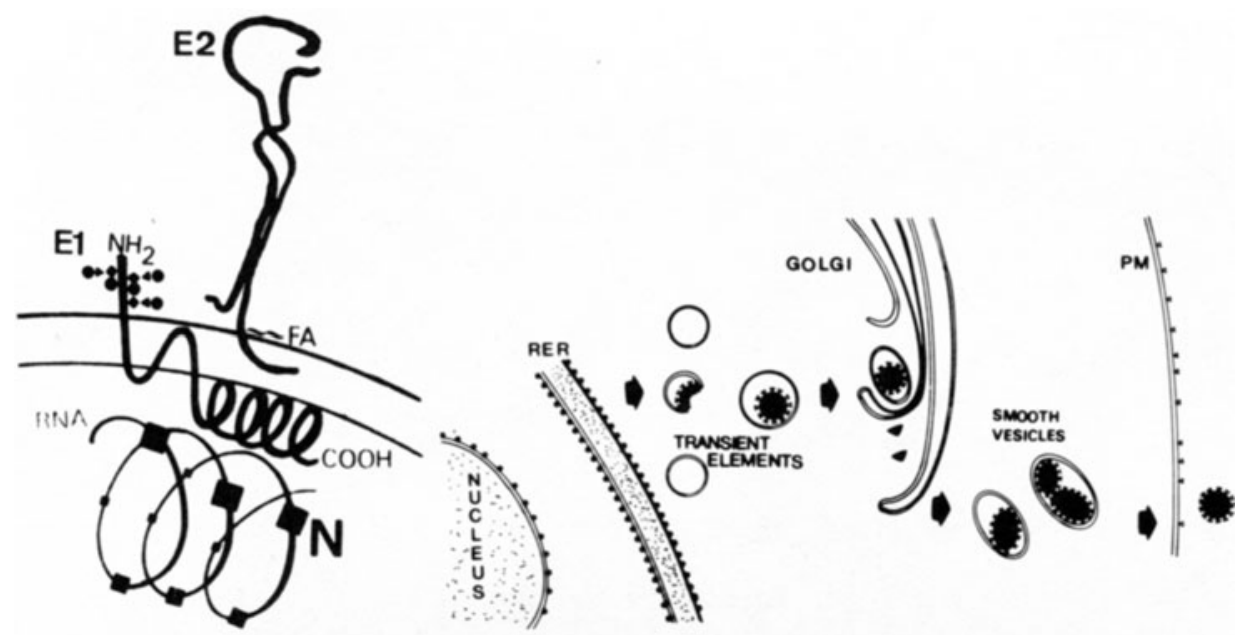

Fig. 1. Structural model of the El-glycoprotein within the viral membrane and schematic drawing of the maturation process of coronaviruses at early stages of virus infection.

\section{Results and Discussion}

\section{Expression of the E1 gene under control of the early SV40 promoter}

The El gene was freed of flanking homopolymeric GC-tails by digestion with AhaIII and FokI. After a filling reaction with Klenow polymerase, BglII linkers were added and the resulting construct was cloned into the BglII site of the SV40 vector p297 (Fig. 2a). Mouse LTK $^{-}$cells were transfected in the presence of the TK gene of herpes simplex virus. After selection for the $\mathrm{TK}(+)$ phenotype, the resulting clones were screened with monoclonal antibodies directed against glycoprotein E1 (10). As shown in Figure 2c, a cell line expressing the E1 protein in perinuclear regions was obtained under such conditions. It should be noted, however, that equivalent cells at this stage did not show any E1 protein at the cell surface as determined by surface immunofluorescent labelling with polyclonal El-specific antibodies. Analyses of chromosomal DNA of such cells indicated that the El gene was indeed integrated into the chromosomal DNA as evidenced by digestion with the restriction enzymes Sau3A and HaeIII (Figure 2b). When, however, these cells were trypsinyzed and passaged for several times to study the synthesis and intracellular transport of El protein by metabolic labelling we realized that deletions within the $3^{\prime}$-region of the E1 gene had occured. At present it is unclear whether the accumulations of the El protein observed in perinuclar regions of the cells are toxic.

Using the same vector under transient expression conditions (Figure $2 a)$, only about $1 \%$ of the transfected cells showed expression of the El gene. Similar unsatisfactory results were obtained when the expression was attempted using DNA expression vectors containing the $69 \%$ fragment of bovine papilloma virus (11) or containing the El-gene under control of the dexamethasone inducible TK-promoter downstream from the MMTV LTR (12). Since such expression levels are too low to study the intracellular transport properties of the El 
protein as well as mutants thereof, we changed to an in vitro system, that allowed the synthesis of mRNA and its subsequent microinjection into fibroblasts or likewise its translation in the absence or presence of pancreatic membranes.
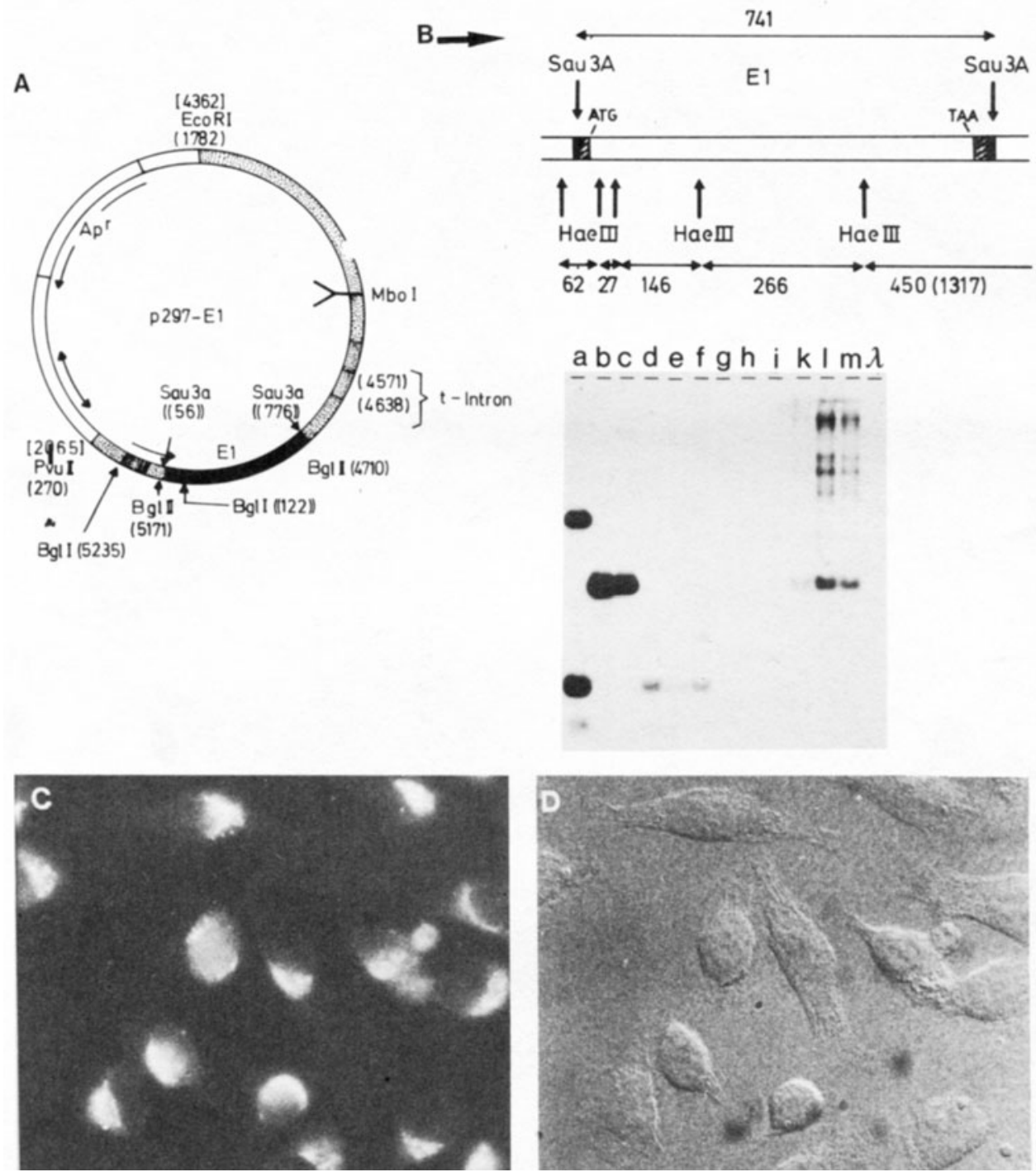

Fig. 2. Expression of the E1-gene of MHV A59 from the SV40-vector p297.

A) Map of the expression vector. Numbers in brackets [ ] refer to pBR322-sequences while numbers in round brackets correspond to SV40sequences. p297-E1-DNA was purified by $\mathrm{CsCl}$ centrifugation and 3.0 $\mu \mathrm{g}$ were used in $\mathrm{Ca}_{3}\left(\mathrm{PO}_{4}\right)_{2}$ transfection experiments together with $100 \mathrm{ng}$ of the $3.6 \mathrm{~kb}$ BamHI-fragment from pSG5 (encoding the thymidine kinase of HSV) (13).

B) Analysis of chromosomal DNA isolated from LTK $^{+}$cells selected after 12 days in HAT-medium. a: 297-El digested with HaeIII; b, c: p297-E1 digested with Sau3A; d, e, f: Chromosomal DNA from three clones of LTK $^{+}$cells digested with HaeIII; $g, h, i$ : Chromosomal DNA from nontrans- 
fected LTK $^{-}$cells; k, 1, m: Chromosomal DNA from LTK $^{+}$clones digested with Sau3A. $\lambda:$ Lambda-DNA digested with HindIII as length markers. C) Analysis of $\mathrm{LTK}^{+}$cells by indirect immunofluorescence with monoclonal anti-El antibody H15 (Repp et a1., 1985).

D) The same cells as in C) but viewed with Nomarski interference contrast optics. The bar corresponds to $20 \mu \mathrm{m}$.

\section{Construction of El transcription vectors}

A DNA fragment containing the complete coding sequence of the E1 protein and additional $20 \mathrm{bp}$ of the coding region of the nucleoprotein of MHV A59 was isolated from the CDNA clone pHN42 by digestion with endonucleases AhaIII and FokI (14). After a filling reaction with Klenow polymerase, BglII linkers were added and the fragment was inserted into the BamHI site of pSP65 (15) to yield pSP65-El (Fig.3).

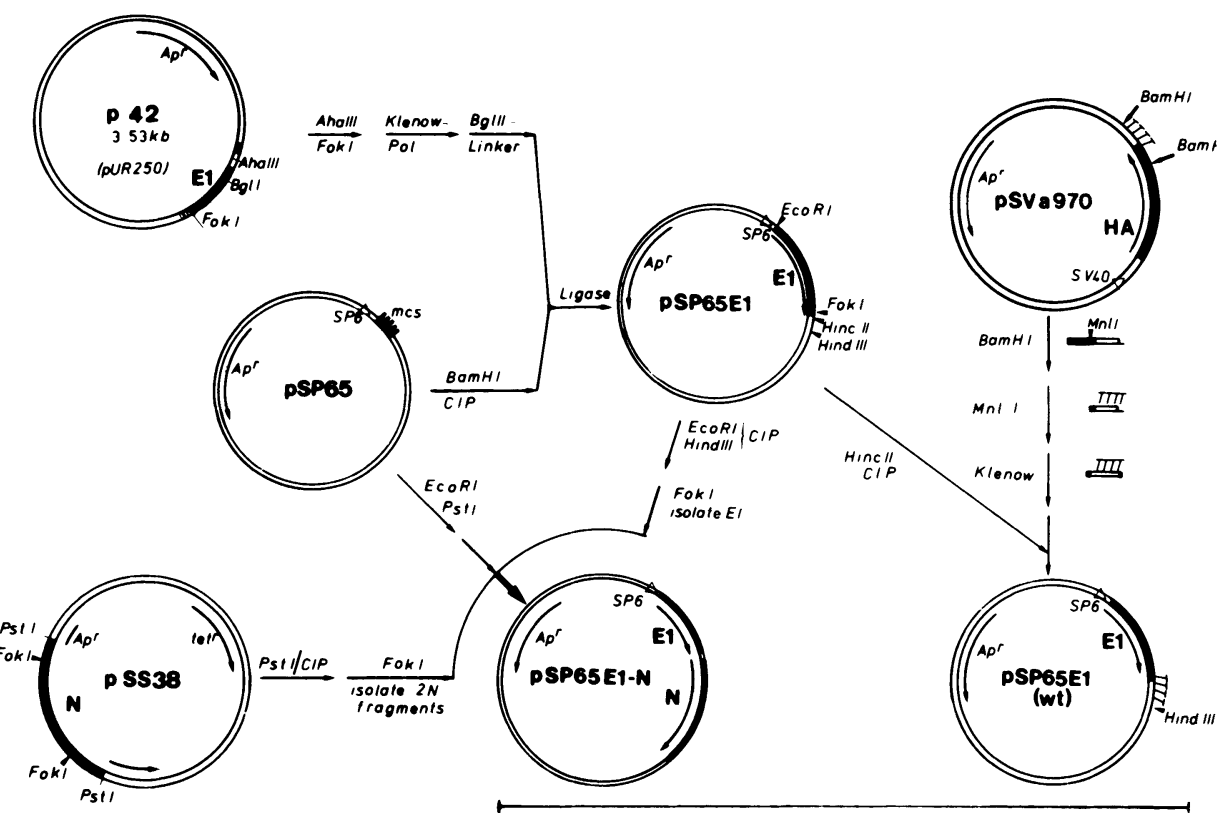

Figure 3. Construction of the in vitro transcription vectors pSP65E1N and PSP65E1

To obtain mRNA which was polyadenylated, a property that has been shown to increase the stability of the corresponding mRNA-species (16), we isolated the (AT)-homopolymer stretch from pSVa970 by digestion with BamHI and MnlI as demonstrated in Figure 3. In addition, to allow for the synthesis of RNA exhibiting all the features of authentic E1-specific mRNA in MHV A59-infected cells, we combined the E1 gene with a gene coding for the nucleoprotein of the JHM-strain of MHV (17) making use of the common FokI site in position 776 of the E1 gene (14). The resulting construct, designated pSP65-E1N contained the authentic gene arrangement present in mRNA No. 6 of MHV-infected cells (18). In this case polyadenylation of the in vitro synthesized mRNA-transcripts was mediated via the authentic poly $(A)$-tail that was originally used in the synthesis of the pSS38 cDNA clone (17). 


\section{Construction of deletion mutants}

To determine whether the $\mathrm{N}$-terminal hydrophilic domain of the El polypeptide played a role in the assembly process into membranes or in intracellular transport, we created deletion mutants. For this purpose we deleted the region from the ScaI site to the AflII site as indicated in Figure 4. In addition, we created various Bal31 deletion mutants downstream from the Scal site. Finally, to delete additional domains, we synthesized specific oligonucleotides and applied those in site-directed mutagenes is using M13-templates grown in E. coli RZ1032 cells (19). This particular E. coli strain contains mutations of the uracil-DNA glucosidase (ung ${ }^{-}$) and of the deoxy-UTPase (dut ${ }^{-}$). Thus, this strain produces M13 DNA that contains uridine residues. After hybridization of the individual 5'-phosphorylated oligonucleotide, a double-stranded heteroduplex form was synthesized by addition of Klenow-polymerase and T4-DNA-1igase. This construct was used to transfect $E$. coli strain 71-18. Since this particular strain is repair(-), as well as dut ${ }^{+}$and ung $^{+}$, preferentially the mutated strand of the double-stranded DNA lacking uridine residues, is transcribed and used for the production of progeny virus.

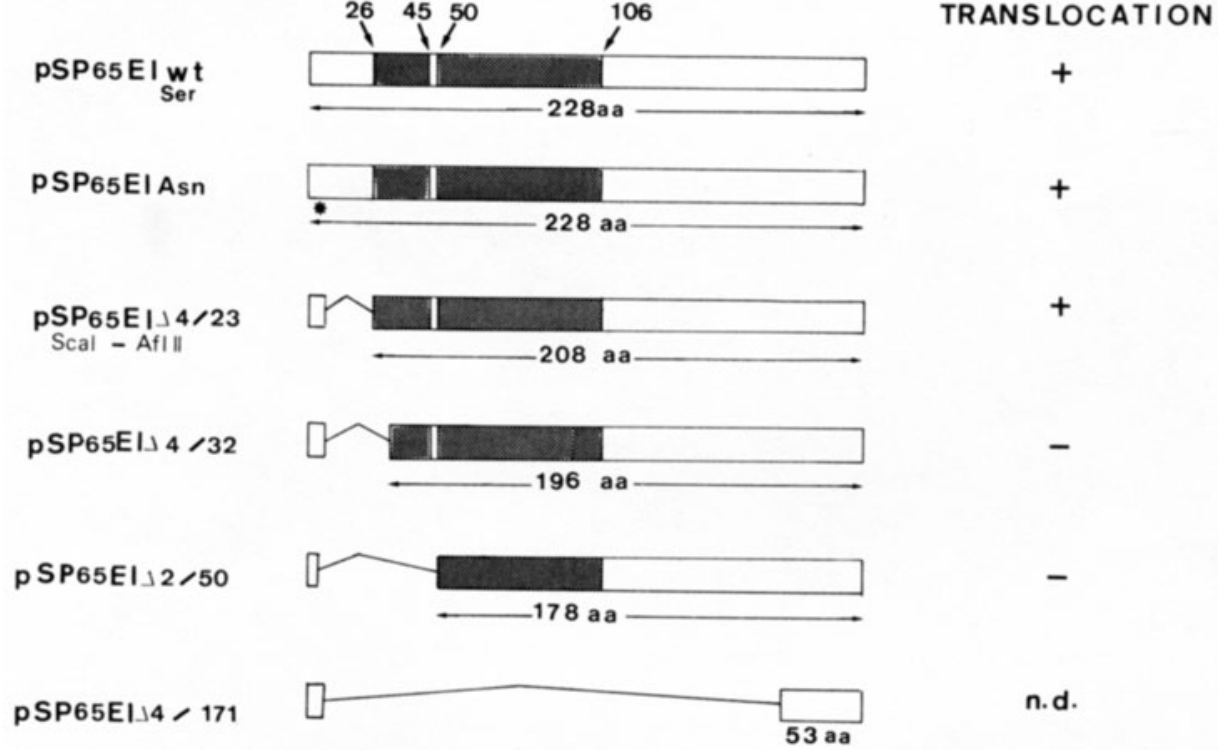

Fig. 4. Schematic drawing of the E1-mutations used in this study.

This approach was also used to mutate the $\mathrm{N}$-terminal attachment sites for the 0-linked carbohydrates. To introduce a sequon Asn-X-Ser(Thr) for $\mathrm{N}$-glycosylation, the second serine residue within the sequence Ser-Ser-Thr-Thr was converted into an asparagine residue.

The individual constructs used in these studies are listed in Figure 4. All mutations were confirmed by dideoxy sequencing in M13 according to Sanger et al., (20). 


\section{Characterization of the mutants by translation in vitro}

The individual mutants were subcloned into pSP65-vectors. Capped and polyadenylated mRNA was synthesized also from the wild type constructs pSP65-E1 and pSP65-E1N according to standard protocols (21). The mRNA was subsequently translated in reticulocyte lysate. The translation of mRNA synthesized from pSP65-E1N yielded exclusively E1-protein as indicated by immunoprecipitation with a polyclonal anti-MHV-serum. Similar results were obtained when wheat germ extract was used in the translation reaction (data not shown).

To study whether or not the individual translation product was capable of integration into microsomal membranes, canine pancreatic membranes were included in the translation mixtures (22). Membrane integration was demonstrated by the resistance of the peptide to proteinase $K$ treatment. As shown in Figure $5 \mathrm{a}$, all mutant El-peptides retaining the complete first hydrophobic sequence were capable of integration into the membranes. The deletion of 19 out of the hydrophilic 24 $N$-terminal amino acids in El $(\Delta 4 / 23)$ did not interfere with this integration process. If, however, 9 additional amino acids including the first six of the first hydrophobic membrane-spanning domain, were deleted, integration into membranes was no longer observed, and, as a result, the protein was degraded by the protease. Deletion of the complete fist hydrophobic domain (E1 2/50) did not uncover a second internal leader peptide. At present, it is not clear whether there is a second hydrophobic leader as has been reported for the bovine opsin, in which each of the membrane-spanning domains provides an independent leader peptide (23).

Figure $5 \mathrm{~b}$ shows the results obtained from the mutant E1-Asn containing the potential $\mathrm{N}$-glycosylation site in the amino terminal domain. In the absence of membranes the molecular weight of the translation product was similar to that of the El-wild-type protein. In the presence of membranes, however, a portion of the translation products showed an increase in molecular weight of about $2 \mathrm{KD}$, in good agreement with the addition of one N-linked oligosaccharide side chain $\left(\mathrm{GlC}_{3}\right.$

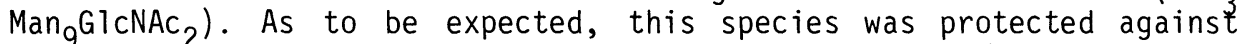
proteinase $K$ due to its integration into membranes. To demonstrate that the observed increase in molecular weight was indeed caused by $\mathrm{N}$-glycosylation of the $\mathrm{N}$-terminus of $\mathrm{E} 1$, we treated a fraction of the translation mixture obtained in the presence of membranes with endoglycosidase $H$. Under these conditions the molecular weight of the El-species was reduced to that of the nonglycosylated protein obtained in the absence of membranes. The molecular weights of the proteolytic degradation prodcuts obtained from the $\mathrm{N}$-glycosylated E1-species differed slightly from those obtained from the nonglycosylated species. At present, we do not know whether these differences are caused by a different folding of the corresponding $\mathrm{N}$-glycosylated polypeptide within the membranes.

Characterization of the individual mutants by microinjection of in vitro synthesized mRNA into various cell lines.

Since our experiments aiming at the expression of the E1 gene from DNA-expression vectors were only partly successful, we microinjected El wildtype and mutant mRNA obtained by in vitro transcription into various cell lines and studied the intracellular distribution of the corresponding polypeptides by indirect immunofluorescence. This procedure has the advantage that large amounts of mRNA can be transfered into a cell of choice, revealing the transport properties of the translation product within 4 to 8 hours after injection. The method has the disadvantage, however, of not permitting metabolic labelling 
studies, since the number of cells is limited to a few hundred.
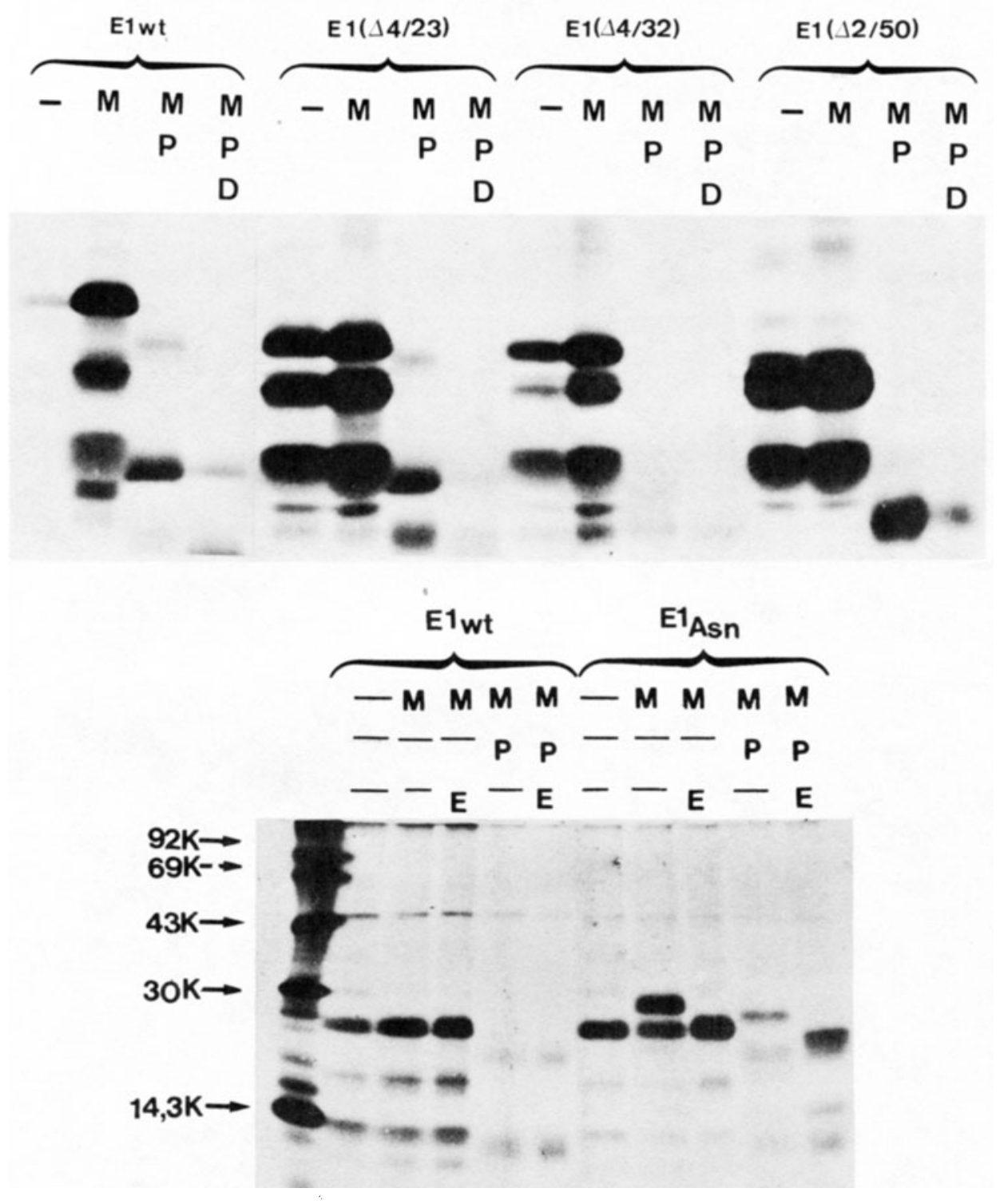

Figure 5. Characterization of the E1-mutants by in vitro translation. A: mRNA synthesized in vitro from PSP65-E1 wild type and mutant vectors was translated in reticulocyte bysates in the absence $(-)$ or presence $(+)$ of membranes (M) using $\left({ }^{3} S\right)$-methionine as radiolabelled amino acid. $P$ indicates that proteinase $K(1 \mathrm{mg} / \mathrm{ml})$ was added for $15 \mathrm{~min}$ at $37^{\circ} \mathrm{C}$ after the completion of translation in the absence or presence of $1 \%$ Triton $X-100$ (D). Samples were analyzed on a $15 \%$ SDS-polyacry 1 amide gel.

B: Transiation of mRNA obtained from pSP65-E1-Asn. Symbols are as in $A) ; E$ indicates samples that were digested with endo- $\mathrm{B}-\mathrm{N}$-acety $\mathrm{T}$ glucosaminidase $\mathrm{H}$. 

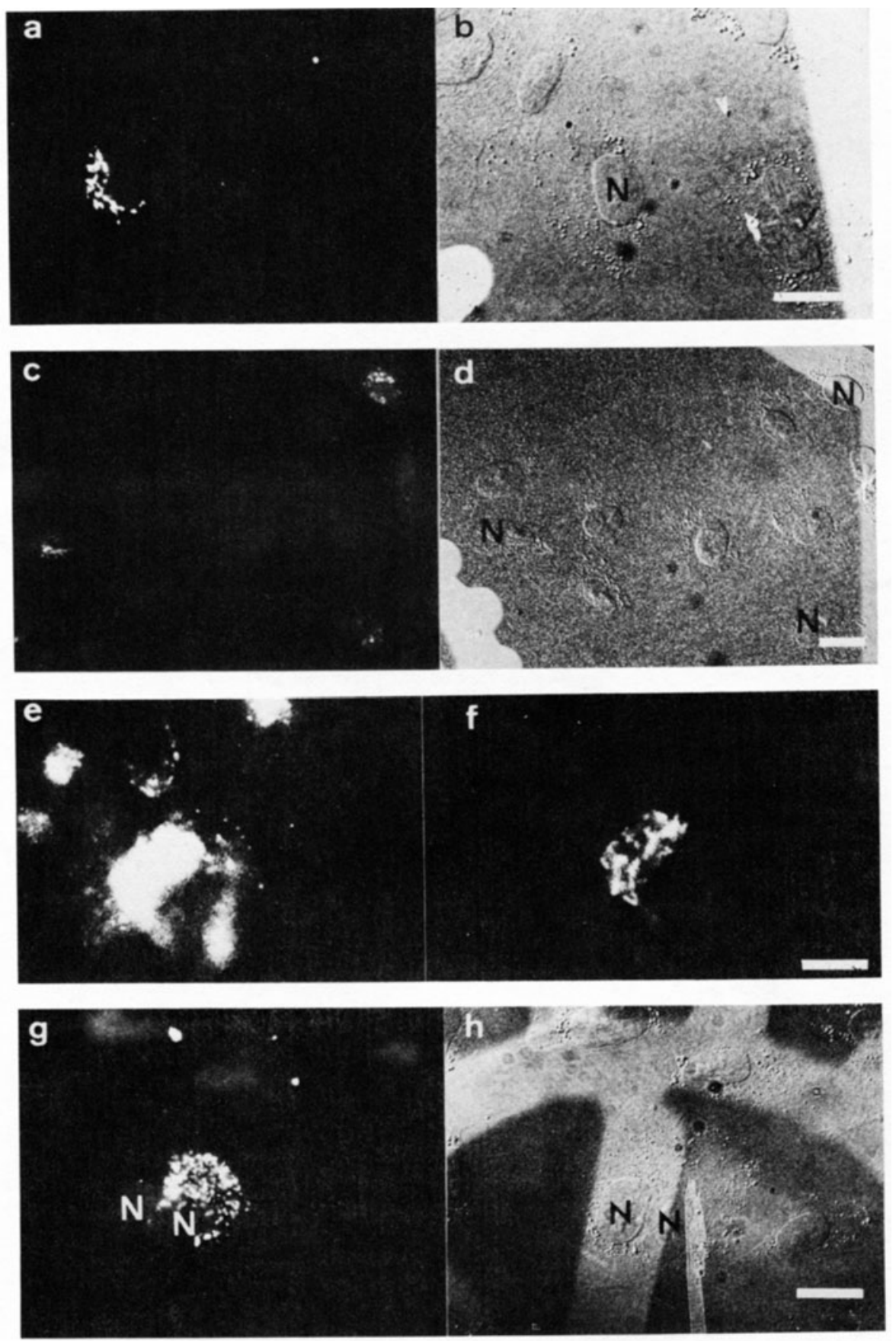

Figure 6. Characterization of the El-mutants by microinjection of mRNA into various cell lines.

A: Wildtype E1-mRNA injected into CV1-cells and assayed $6 \mathrm{~h}$ after injection with monoclonal El-antibody and FITC-conjugated goat anti- 
mouse IgG. B: same cell as in A) viewed by Nomarski interference contrast optics. C: mRNA obtained from pSP65-E1N, monoclonal E1-antibody. $D$ : same cells as in (), but viewed by Nomarski interference. E: AtT20cells injected with mRNA from pSP65-E1, anti-ACTH rabbit serum and rhodamine-conjugated goat-anti-rabbit-serum were used to detect ACTH. $F$ : same cells as in $E)$, monoclonal El-antibody as first antibody. G: mRNA from pSP65-E1 $\Delta 4-32$ was injected into CV1-cells. Cells were fixed and investigated $6 \mathrm{~h}$ after injection using monoclonal E1-antibody. $H$ : same cells as in G), viewed with Nomarski interference. The bar corresponds to $20 \mu \mathrm{m}$.

Figure 6 a shows that CV1-cells injected with capped and polyadenylated E1-wildtype mRNA expressed the E1 polypeptide exclusively in perinuclear regions. Sister cultures injected with the identical mRNA-preparation revealed no El polypeptide at the cell surface as judged by staining with polyclonal MHV-antibody and peptide-specific antibody $\mathrm{H}-2$ (data not shown).

A similar perinuclear E1-distribution was observed when E1N-mRNA obtained from PSP65-EIN was injected (Figure 6c). No N-Protein was synthesized from this mRNA, indicating that this E1N-mRNA-species acts monocistronically (data not shown).

To determine whether the accumulation of the E1 peptide was also observed in secretory cells, AtT20-cells were also injected with E1-mRNA. Again the El protein was restricted to the Golgi region and little or no El was detected in secretory granules at the periphery of the cells (Figure $6 \mathrm{f}$ ). These secretory granules contained mature adenocorticotropin as revealed by staining with an ACTH-specific antibody (Figure 6e). Together, these results show that the E1 protein carries a signal for accumulation in perinuclear regions and thus determines the site of virus maturation (8).

In contrast, the deletion of six of the hydrophobic amino acids from the first membrane-spanning domain of El caused the corresponding
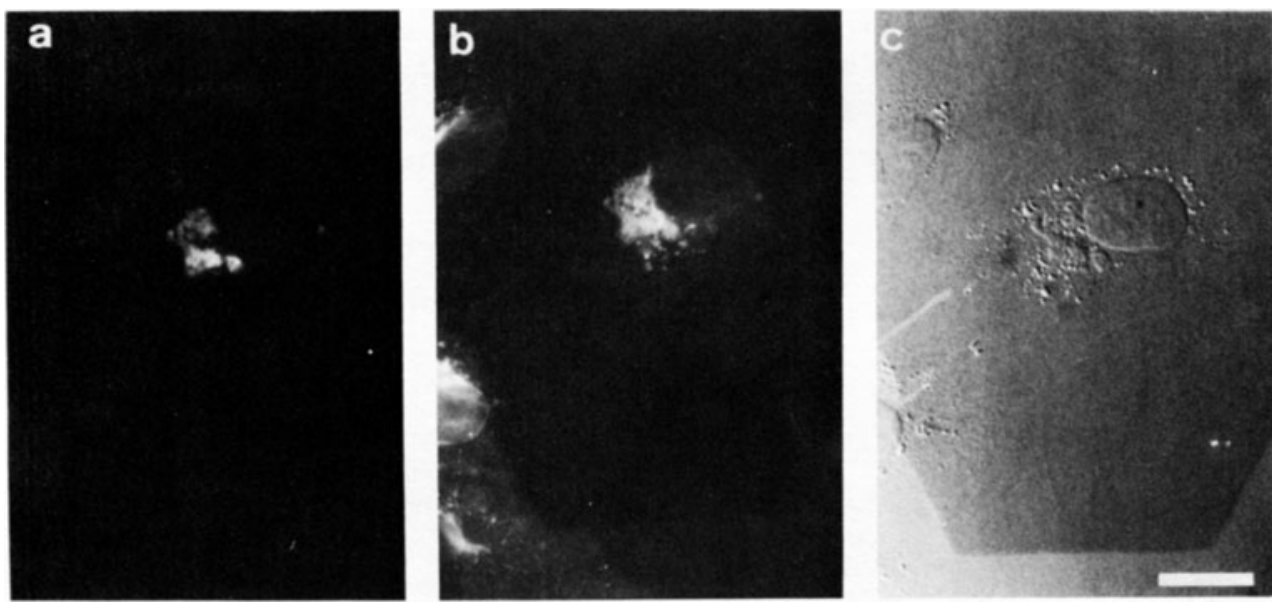

Figure 7. Microinjection of mRNA from pSP65-E1-Asn into CV1-cells.

A: Cells were fixed $6 \mathrm{~h}$ after injection and stained with monoclonal E1-antibody using FITC-conjugated goat-anti-mouse-IgG as second antibody. B: same cells as in A), stained with rhodamine-conjugated wheat germ agglutination. C: same cells as in A), viewed by Nomarski interference contrast optics. 
peptide-species to form aggregates within the cytoplasm. Figure $6 \mathrm{~g}$ demonstrates that the E1-species obtained from mutant pSP65-E1 $\Delta$ $4 / 32$ no longer accumulated in Golgi-specific regions of the injected cells. This finding again indicates that the first membrane domain of the El polypeptide functions as a leader peptide for membrane integration.

As to be expected from the relatedness of the intracellular maturation sites of MHV and IBV, the latter of which carries an E1 protein with two putative $\mathrm{N}$-glycosylation sites, the E1-Asn mutant peptide (Figure 7a) showed a distribution that was indistinguishable from that of wildtype El (Figure 6a) and of rhodamine-conjugated wheat germ agglutinin which binds specifically to the Golgi membranes (Figure 7b). Neither cells injected with wildtype El-mRNA, nor cells expressing the El-Asn variant, showed El protein at the cell surface as judged by indirect immunofluorescence labelling with a polyclonal MHV A59antiserum or with a peptide-specific antibody recognizing the $\mathrm{N}$-terminal nonglycosylated domain of EI (Figure 8). In MHV-infected $17 \mathrm{Cl} 1$-cells this latter antibody recognized the El peptide predominantly in membranes of the RER.

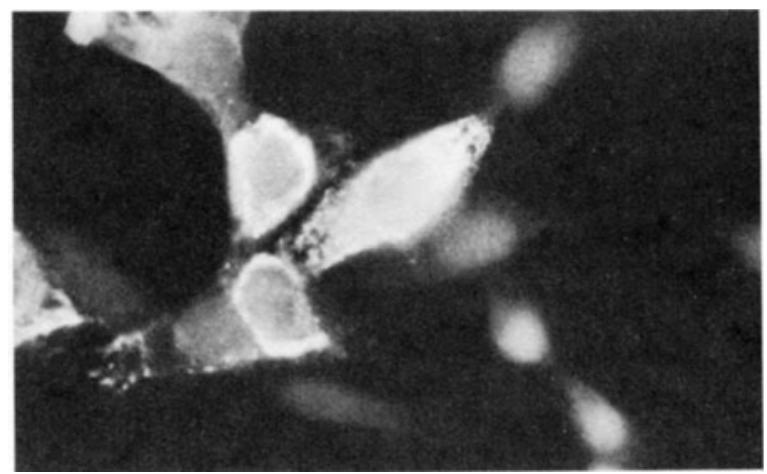

Figure 8. Detection of the E1 protein in MHV A59-infected 17C11-cells with a peptide-specific antibody

Cells were fixed $6 \mathrm{~h}$ after infection and subjected to indirect immunofluorescence using an antibody raised against the peptide 'Ser-SerThr-Thr-Gin-Ala-Pro-Tyr' as described in Materials and Methods.

Further studies of the intracellular transport are required in order to identify the final transport route of the El protein after its accumulation in Golgi membranes as well as to study the extent of post-translational processing of the El protein in terms of glycosylation. Such studies, based on the expression of the El gene from vaccinia vectors, are currently being performed.

\section{MATERIALS AND METHODS}

\section{Cells and Viruses}

The A59 strain of mouse hepatitis virus was grown in sac(-)-cells, a nonproducer Moloney sarcoma 1 ine. For DNA transfection and microinjection of mRNA, mouse LTK $^{-}$- or CV1-primate cells were used. AtT20-cells, descendents of a mouse LAF1 pituitary tumor, were kindly provided 
by J. Tooze, (EMBL, Heidelberg). All cells were grown in DMEM in the presence of $5 \%$ fetal calf serum ( LTK $^{-}$and CV1) or $10 \%$ horse serum (AtT20-ce11s).

\section{Enzymes, chemicals and radiochemicals}

Restriction endonucleases FokI and MnlI were from New England Biolabs (Schwalbach/Ts., FRG). A11 other restriction enzymes, DNA-polymerase (Klenow fragment), SP6-RNA-polymerase, T4-DNA-1igase, 7-mGpppG, yeasttRNA, and oligo(dT)-cellulose were from Boehringer (Mannheim, FRG). Wheat germ extract, reticulocyte lysate, and nuclease-free bovine serum albumine were from Bethesda-Research-Laboratories. Nonlabelled nuclegtodies were obtained from PL-Pharmacia (Freiburg, FRG).

$\left(\alpha-{ }^{35} \mathrm{~S}\right)$-UTP $(<400 \mathrm{Ci} / \mathrm{mmol}),\left(\gamma-{ }^{32} \mathrm{P}\right)$-ATP $(<400 \mathrm{Ci} / \mathrm{mmol})$, and $\left({ }^{35} \mathrm{~S}\right)-$ methionine $(800 \mathrm{Ci} / \mathrm{mmol})$ were from Amersham-Buchler (Braunschweig, FRG).

\section{Plasmids}

The construction of E1-specific CDNA in pUR250 and sequencing of the El gene of MHV A59 has been described previously (3, 14). Plasmid pSS38, harboring the gene for the nucleocapsid protein of the JHM strain of MHV, has been published (17). The expression vector pSVa970 which contained the hemagglutinin gene of the influenza A virus (strain Victoria 3/75; H3N2) was used as a source of a poly(A) block. It was kindly provided by Dr. J. Ortin (University of Madrid, Spain) and has been described by Min Jou et al. (24). The SV40-vector p297 was obtained from P. Gruss (Heidelberg, FRG). The vector pSP65 was purchased from Progema (Heidelberg, FRG).

\section{Transcription of modified pSP65-vectors}

Recombinant pSP65-DNA was linearized with HindIII and dissolved at $0.1 \mu \mathrm{g} / \mu \mathrm{l}$ in $500 \mu \mathrm{l} 40 \mathrm{mM}$ Tris- $\mathrm{HCl}$, $\mathrm{pH} \mathrm{7.5}$, containing $6 \mathrm{mM} \mathrm{MgCl}$, $2 \mathrm{mM}$ spermidine, $10 \mathrm{mM} \mathrm{NaCl}, 100 \mu \mathrm{g} / \mathrm{ml}$ BSA, $10 \mathrm{mM}$ DTT, $0.5 \mathrm{mM} \mathrm{AT \beta}$, CTP, UTP, $0.05 \mathrm{mM} \mathrm{GTP,} 0.5 \mathrm{mM} 7-\mathrm{mGpppG}$, and $1.0 \mathrm{U} / \mu 1 \mathrm{RNasin}$. The reaction was started by the addition of $50 \mathrm{U}$ SP6-polymerase. After $1 \mathrm{~h}$ at $40^{\circ} \mathrm{C}$, another $50 \mathrm{U}$ of polymerase were added and the reaction was continued for $30 \mathrm{~min}$. The reaction mixture was extracted with phenol/chloroform and precipitated with ethanol. Polyadenylated mRNA was isolated by oligo(dT)-chromatography as described by Aviv and Leder, (25), precipitated and resuspended in $15 \mu 1$ distilled water.

\section{In vitro translations}

Poly(A)-RNA from MHV A59-infected cells or RNA synthesized in vitro was translated in wheat germ extract or reticulocyte lysate as described previously $(26,27)$. ( $\left.{ }^{35}\right)$-methionine was used to label the newly synthesized proteins. In some experiments dog pancreas membranes (Amersham-Buchler, Braunschweig, FRG) were added. Translations were performed according to the suppliers manual.

CV1- or LTK- -cells were seeded $24 \mathrm{~h}$ before injection on pretreated glass-coverslips and incubated in DMEM containing $10 \%$ fetal calf serum.

Preparation of cover slips for microinjection: Glas-coverslips (15 $\mathrm{mm}$ in diameter) were defattened in acetone for $3 \mathrm{~h}$, dried with Kim wipes and treated overnight with $0.2 \%(\mathrm{w} / \mathrm{w}) \mathrm{Na}_{2} \mathrm{CO}_{3}$. After 5 washes with distilled water coverslips were transferred onto filter paper and were air dried. To a suspension of the white of an egg in 500 
$\mathrm{ml} 20 \mathrm{mM} \mathrm{NaOH}, 4 \mathrm{ml}$ polyvinylpyrrolidone-solution $(25 \% \mathrm{w} / \mathrm{vol}$ in distilled water) was added and this mixture was stirred at room temperature for $2 \mathrm{~h}$. The mixture was then cleared by filtration. The cover slips were placed into the filtrate and incubated for $2 \mathrm{~h}$ at $65^{\circ}$ C. After a quick rinse with distilled water the cover slips were fixed at room temperature for $20 \mathrm{~min}$ in ethanol/glacial acetic acid (3:1) and air dried. The cover slips were then incubated in $0.1 \mathrm{M}$ triethanolamine/ $\mathrm{HCl}$ ( $\mathrm{pH} 8.0$ ) containing $0.25 \%$ (vol/vol) acetic anhydride. Subsequently they were washed with ethanol-water mixtures ranging from $60 \%$ (Vol/vol) ethanol to $100 \%$ ethanol. Cover slips were sterilized by overnight exposure to UV-light. Several 200 mesh copper alphabet finder grids used in electron microscopy were placed onto the coated coverslips in a vacuum chamber. A gold layer of about $500 \mathrm{~nm}$ thickness was evaporated onto the surface resulting in a visible shadow image of the grid bars.

\section{Antisera}

The production of a polyclonal anti-MHV A59 antiserum in rabbits has been described previously (29). For the production of the peptidespecific $\mathrm{H}-2$ antiserum which reconizes the nonglycosylated aminoterminus of the E1 polypeptide, $10 \mathrm{mg}$ of peptide were coupled covalently to key hole limpet hemocyanine. Rabbits were immunized with the complex in the presence of complete Freund's adjuvant and antibodies were purified essentially as described by Tamura et al. (28). Anti-GMT1serum recognizing the glycosylated aminoterminus of glycoprotein E1 was prepared as follows: $5 \mathrm{mg}$ of the $\mathrm{N}$-terminal tryptic peptide 1 of glycophorin A (kindly provided by Dr. H. Furthmayr, Yale University) was dissolved in $1 \mathrm{ml}$ of distilled water $/ \mathrm{HCl}$, $\mathrm{pH} 3.0$, containing $5 \mathrm{mg}$ of water soluble 1-ethyl-3-(3-dimethylaminopropy 1)carbodiimid (Sigma, Deisenhofen, FRG). After 15 min at $0^{\circ} \mathrm{C}$ the $\mathrm{pH}$ was adjusted to $\mathrm{pH} 9.0$ by the addition of $\left(\mathrm{NH}_{4}\right)_{2} \mathrm{CO}_{3}$ and $1 \mathrm{~g}$ of $\mathrm{AH}$-Sepharose $4 \mathrm{~B}$ (PL-Pharmacia, Freiburg, FRG) was added. This mixture was incubated for $3 \mathrm{~h}$ at room temperature on a shaker. The column material was washed and excessive active groups were blocked by acetic acid as described in the manufactorer' manual). To allow optimum binding of IgG from the anti-MHV A59 antiserum, the column material was rotated end over end in a test tube with $2 \mathrm{ml}$ of antiserum at $4^{\circ} \mathrm{C}$ over night. The material was then packed into a Bio-Rad column $(0.7 \times 10 \mathrm{~cm})$ and rinsed twice with 10 column volumes of PBS, followed by 10 volumes of PBS containing $0.5 \mathrm{M} \mathrm{NaCl}$. This washing procedure was repated twice. Bound IgG was eluted with $0.1 \mathrm{M}$ glycine/HCl, $\mathrm{pH} 2.5$, and the eluted fractions were immediately neutralized by the addition of tris-base.

\section{Immunoprecipitation}

The immunoprecipitation of MHV-specific polypeptides from labelled cell lysates has been described previously (29). To identify proteins from in vitro translation assays, $5 \mu 1$ of translation mixture were mixed with $25 \quad \mu 1$ RIPA-buffer ( $50 \mathrm{mM}$ Tris- $\mathrm{HCl}$, pH 7.2, $10 \mathrm{mM}$ EDTA, $1 \%(\mathrm{w} / \mathrm{vol})$ Triton-X100, $1 \%(\mathrm{w} / \mathrm{w})$ sodium deoxycholate, $0.1 \%$ (w/vol) sodium dodecylsulfate and $5 \%$ (vol/vol) Trasylol. The polyclonal anti-MHV A59 rabbit serum $(2 \mu 1)$ was added and the immune complexes were adsorbed to protein A-bearing Staphylococcus aureus as described previously (29). 


\section{Digestion with endo-N-acetylglucosaminidase $\mathrm{H}$}

Aliquots of the translation mixture $(1.25 \mu 1)$ were diluted with 3.75 41 gel loading buffer (30) and boiled for 1 min. After addition of $40 \mu 1$ Tris/HCl-buffer (250 mM, pH 6.8 and $0.2 \%$ SDS) samples were treated for $20 \mathrm{~h}$ with $15 \mu \mathrm{U}$ endo- $\beta$-acetylglucosaminidase $\mathrm{H}$ (Miles, Frankfurt, FRG) at $37^{\circ} \mathrm{C}$.

\section{Acknowledgement}

We thanks Drs. P. Gruss, J. Ortin and S. Siddell for plasmids and

M. Rosing for excellent technical assistance. This work was supported by research grant $\mathrm{Ni} 175 / 5$ (intracellular transport signals) from the Deutsche Forschungsgemeinschaft. T. M. ist the recipient of a grant from the Graduiertenförderung der Justus-Liebig-University, Gießen.

\section{REFERENCES}

1. Sturman, L. S. and Holmes, K. V. (1984). Proteolytic cleavage of peplomeric glycoprotein E2 of MHV yields to 90K subunits and activates cell fusion. Adv. Exptl. Med. Biol. 173,25-35.

2. Niemann, H., Geyer, R., Klenk, H.-D., Linder, D., Stirm, S., and Wirth, M. (1984). The carbohydrates of mouse hepatitis virus (MHV A59): Structures of the 0-glycosidically-linked oligosaccharides of glycoprotein E1. The EMBO J. 3, 665-670.

3. Armstrong, J., Niemann, H., Smeekens, S., Rottier, P. and Warren, G. (1984). Sequence and topology of a model intracellular membrane protein, E1 glycoprotein, from a coronavirus. Nature 308, 751752 .

4. Rottier, P., Welling, G. W., Welling-Wester, S., Niesters, H., Lenstra, J. A. and van der Zeijst, B. A. M. (1986). Predicted membrane topology of the coronavirus protein E1. Biochemistry 25, $1335-1339$.

5. Niemann, H., Boschek, B., Evans, D., Rosing, M., Tamura, T. and Klenk, H.-D. (1982). Post-translational glycosylation of coronavirus glycoprotein E1: Inhibition by monensin. The EMBO J. 1, 14991504.

6. Doller, E. W. and Holmes, K. V. (1980). Different intracellular transportation of the envelope glycoproteins E1 and E2 of the coronavirus MHV. Am. Soc. Microbiol. Abstr. Annu. Meet. Abstract T190.

7. Becker, W. B., McIntosh, K., Dees, J. H. and Chanock, R. (1967). Morphogenesis of avian infectious bronchitis virus and a related human virus (strain 229E). J. Virol. 1, 1019-1027.

8. Holmes, K. V., Doller, E. W. and Behnke, J. N. (1981). Analysis of the functions of coronavirus glycoproteins by differential inhibition with tunicamycin. Adv. Exp. Med. Biol. 142, 133-139.

9. Tooze, J., Tooze, S. and Warren, G. (1984). Replication of coronavirus MHV-A59 in sac-cells: Determination of the first site of budding of progeny virus. Eur. J. Cell. Biol. 33, 281-293. 
10. Repp, R., Tamura, T., Boschek, C. B., Wege, H., Schwarz, R. T. and Niemann, H. (1985). The effects of processing inhibitors of $\mathrm{N}$-linked oligosaccharides on the intracellular migration of glycoprotein E2 of mouse hepatitis virus and the maturation of coronavirus particles. J. Biol. Chem. 260, 15873-15879.

11. Meneguzzi, G., Binetruy, M., Grisoni, M. and Cuzin, F. (1984). Plasmidial maintenance in rodent fibroblasts of BPV-1-pBR322 shuttle vector without immediately apparent oncogenic transformation of recipient cells. The EMBO J. 3, 365-371.

12. Ponta, H., Kennedy, N., Skroch, P., Hynes, N. E. and Groner, B. (1985). The hormonal response region in the mouse mammary tumor virus long terminal repeat can be dissociated from the proviral promoter and has enhancer properties. Proc. Natl. Acad. Sci. USA 82, 1020-1024.

13. Colbere-Garapin, F., Chousterman, S., Horodniceanu, F., Kourilsky, P. and Garapin, A.-C. (1979). Cloning of the active thymidine kinase of herpes simplex virus type I in Escherichia coli K12. Proc. Nat1. Acad. Sci. USA 76, 3755-3759.

14. Niemann, H., Heisterberg-Moutsis, G., Geyer, R., Klenk, H.-D. and Wirth, M. (1984). Glycoprotein E1 of MHV-A59: Structure of the $0-1$ inked carbohydrates and construction of full length recombinant cDNA clones. Adv. Expt1. Med. Biol. 173, 201-213.

15. Krieg, P. A. and Melton, D. A. (1984). Functional messenger RNA are produced by SP6 polymerase in vitro transcription of cloned cDNA. Nucl. Acids Res. 12, 7057-7070.

16. Huez, G., Bruck, C. and Cleuter, Y. (1981). Translational stability of native and deadenylated rabbit globin mRNA injected into HeLa cel1s. Proc. Nat1. Acad. Sci. USA 78, 908-911.

17. Skinner, M. A. and Siddel1, S. G. (1983). Coronavirus JHM: Nucleotide sequence of the mRNA that encodes nucleocapsid protein. Nuc1. Acids Res. 11, 5045-5054.

18. Spaan, W., Delius, H., Skinner, M., Armstrong, J., Rottier, P., Smeekens, S., van der Zeijst, B.A.M. and Siddel1, S. (1983): Coronavirus mRNA synthesis involves fusion of non-contigous sequences. The EMBO J. 2, 1839-1844.

19. Kunke1, T. A. (1985). Rapid and efficient site-specific mutagenesis without phenotypic selection. Proc. Natl. Acad. Sci. USA 82, 488-492.

20. Sanger, F., Nicklen, S. and Coulson, A. R. (1977). DNA-sequencing with chain terminating inhibitors. Proc. Natl. Acad. Sci. USA 74, 5463-5467.

21. Drummond, D. R., Armstrong, J. and Colman, A. (1985). The effect of capping and polyadenylation on the stability, movement and transiation of synthetic messenger RNAs in Xenopus oocytes. Nucl. Acids Res. 13, 7375-7394. 
22. Rottier, P., Brandenburg, D., Armstrong, J., van der Zeijst, B. A. M. and Warren, G. (1985). Assembly in vitro of a spanning membrane protein of the endoplasmic reticulum. The El-glycoprotein of coronavirus mouse hepatitis virus A59. Proc. Nat1. Acad. Sci. USA $81,1421-1425$.

23. Friedlander, M. and Blobel, G. (1985). Bovine opsin has more than one signal sequence. Nature $318,338-343$.

24. Min Jou, W., Verhoeyen, M., Devos, R., Saman, E., Fang, R., Huylebroeck, D. and Fiers, W., Threlfal1, G., Barber, C., Carey, N. and Emtage, S. (1980). Complete structure of the hemagglutinin gene from the human influenza A/Victoria/5/75 (H3N2) strain as determined from cloned cDNA. Cel1 19, 683-696.

25. Aviv, H. and Leder, P. (1972). Purification of biologically active globin messenger RNA by chromatography on oligothymidilylic acid cellulose. Proc. Nat1. Acad. Sci. USA 69, 1409-1412.

26. Anderson, C. W., Strauss, J. W. and Dudoch, B. S. (1983). Preparation of a cell-free protein synthesizing system from wheat germ. Methods Enzymol. 101, 635-644.

27. Jackson, R. J. and Hunt, T. (1983). Preparation and use of nuclease treated rabbit reticulocyte lysates for the translation of eukaryotic messenger RNA. Methods Enzymol. 96, 50-74.

28. Tamura, T. and Bauer, H.; Birr, C. and Pipkorn R. (1983). Antibodies against synthetic peptides as a tool for functional analysis of the transforming protein pp60 src . Cell 34, 587-596.

29. Niemann, H. and Klenk, H.-D. (1981). Coronavirus glycoprotein El, a novel type of viral glycoprotein. J. Mol. Biol. 153, 9931010 .

30. Laemmli, U. K. (1970). Cleavage of structural proteins during the assembly of the head of bacteriophage T4. Nature 227, 680685 . 